\title{
KOMODITI PANGAN (PADI, JAGUNG DAN KEDELAI) UNGGULAN DAERAH KOTA DI PROVINSI SUMATERA
} BARAT

\author{
Leading Commodity (Rice, Corn And Soybean) In City Region in \\ West Sumatera Province
}

Syahrial| ${ }^{1}$ dan Welly Herman ${ }^{1}$

Diterima: 6 Agustus 2018 Disetujui: 23 November 2018

\begin{abstract}
Abstrak: Pangan menjadi hajat bagi seluruh penduduk baik di daerah perdesaan maupun di perkotaan sehingga ketersediaan pangan harus terjamin untuk memenuhi kebutuhan semua penduduk. Beberapa program pemerintah telah banyak dilakukan guna mencapai swasembada pangan khususnya padi, jagung dan kedelai. Penelitian ini bertujuan untuk (1) mengidentifikasi komoditi pangan unggulan daerah kota di Provinsi Sumatera Barat. (2) menganalisis spesialisasi dan lokalisasi komoditi pangan unggulan daerah kota di Provinsi Sumatera Barat. (3) mengidentifikasi komoditi pangan prioritas yang bisa dikembangkan daerah kota di Provinsi Sumatera Barat. Penelitian ini dilakukan di (7) tujuh daerah kota di Provinsi Sumatera Barat. Penelitian ini menggunakan data sekunder yang meliputi produksi, harga dan nilai produksi. Hasil analisis menunjukkan bahwa (1) hanya komoditi padi menjadi komoditi unggulan di semua daerah kota, (2) komoditi pajale menyebar di daerah beberapa kecamatan di semua daerah kota, (3) dan hanya komoditi padi yang menjadi komoditi prioritas di beberapa daerah kota. Sehingga pengembangan komoditi pangan di daerah kota di Provinsi Sumatera Barat bisa diprioritaskan pada komoditi padi guna memenuhi kebutuhan pangan penduduknya.
\end{abstract}

\section{Kata Kunci: Komoditi Unggulan, Pajale, Pangan}

\begin{abstract}
Food is a necessity for all residents in both rural and urban areas so that food availability must be guaranteed to meet the needs of all residents. Several government programs have been carried out to achieve food self-sufficiency, especially rice, corn and soybeans. This study aims to (1) identify the leading food commodities in the city in West Sumatra Province. (2) analyzing the specialization and localization of superior food commodities in the city in West Sumatra Province. (3) identifying priority food commodities that can be developed in urban areas in West Sumatra Province. This research was conducted in (7) seven urban areas in West Sumatra Province. This study uses secondary data which includes production, price and production value. The results of the analysis showed that (1) only rice commodities became the main commodity in all urban areas, (2) pajale commodities spread in several districts in all urban areas, (3) and only rice commodities became priority commodities in several urban areas. So that the development of food commodities in urban areas in West Sumatra Province can be prioritized on rice commodities to meet the food needs of its population.
\end{abstract}

Keywords: Featured commodities, Food, Pajale

\footnotetext{
${ }^{1}$ Universitas Tamansiswa, Jalan Tamansiswa No. 9 Padang, Sumatera Barat
} 


\section{PENDAHULUAN}

Pangan merupakan komoditi pertanian yang menjadi kebutuhan pokok bagi masyarakat. Ketersediaan pangan harus mampu memenuhi permintaan pangan di perkotaan maupun perdesaan. Karena baik penduduk kota maupun desa sama-sama membutuhkan pangan untuk keberlangsungan hidup mereka. Maka tidak heran jika presiden pertama Republik Indonesia yaitu Ir. Soekarno pernah menyatakan bahwa "Soal pangan adalah soal hidup-matinya bangsa”. Dari pernyataan tersebut, kita mengetahui bagaimana peran vital ketersediaan pangan bagi masyarakat. Tanpa ketersediaan pangan yang mencukupi bisa mengakibatkan krisis pangan.

Indonesia telah mengalami beberapa pergantian presiden, namun masalah ketersediaan pangan tetap menjadi perhatian dan program penting bagi pemerintah. Mulai dari pemerintahan orde lama, Presiden Soekarno telah mencanangkan swasembada beras melalui program kesejahteraan kasimo dan program sentra padi (Lassa, 2005). Dan pada orde baru, Presiden Soeharto yang berhasil mencapai swasembada beras pada tahun 1984 melalui program revolusi hijau. Kemudian pada era pemerintahan selanjutnya masih melanjutkan program untuk mencapaian swasembada beras. Namun sampai saat ini prestasi yang pernah tercapai pada tahun 1984 belum bisa terulangi lagi (Sumarno, 2015).

Ada beberapa permasalahan yang menyebabkan pemerintah tidak mampu mencapai swasembada pangan. Permasalahan itu antara lain lebih mengutamakan pangan pokok beras dibandingan dengan komoditi pangan lain, lebih memperhatian lahan sawah dibandingkan sumber daya lahan lain, lebih memperhatikan potensi kawasan barat Indonesia dibandingkan kawasan timur Indonesia, lebih berorientasi ketahanan pangan nasional dibandingkan ketahan pangan regional dan rumah tangga, lebih mengutamakan komoditi berbasis impor dibandingkan komoditi basis lokal dan kurangnya penguatan daya tahan pertanian dalam negeri (Rachmat, 2015). Menurut (Prabowo, 2010) konsep ketahanan pangan bukan hanya mengenai ketersediaannya saja, melainkan ada faktor lain yang harus dipenuhi dalam ketahanan pangan, yaitu faktor distribusi dan konsumsi. Permasalahan tersebutlah yang mengakibatkan kondisi pertanian khususnya pangan tidak mampu mencapai produksi yang optimal untuk memenuhi kebutuhan dalam negeri sehingga sampai saat ini pemerintah harus mengimpor beras.

Berdasarkan data yang diperoleh dari (Pertanian, 2015) menunjukkan bahwa volume impor beras pada tahun 2013 sebesar 472.665 ton yang kemudian meningkat menjadi 844.164 ton pada tahun 2014. Artinya pertembuhan impor beras Indonesia mencapai 78,89 persen. Volume impor beras dipengaruhi ketersediaan stok beras dan jumlah permintaan dalam negeri.

Impor beras akan berdampak pada ketersediaan dan penurunan harga di tingkat nasional. Namun, di sisi lain impor beras juga berdampak juga pada penurunan PDB rill, tingkat investasi, stok modal dan penyerapan tenaga kerja lokal (Horridge, Wittwer, \& Wibowo, 2006). Jika impor beras terus dilakukan dan dengan jumlah yang terus meningkat maka perekonomian Indonesia akan terus dirugikan. Sehingga diperlukan upaya yang tepat untuk memenuhi kebutuhan pangan dengan memaksimalkan produksi lokal.

Program yang dilakukan oleh pemerintahan era Joko Widodo untuk memenuhi kebutuhan pangan dengan meningkatkan produksi lokal cukup optimistis. Di mana pada tahun awal masa pemerintahannya sudah mencangkan bahwa Indonesia mampu mencapai swasembada tiga komoditi pangan yaitu padi, jagung dan kedelai dalam waktu empat tahun. Upaya pemerintah tersebut diwujudkan melalui Kementerian Pertanian mengeluarkan peraturan Menteri Pertanian No.14 Tahun 2015 tentang kebijakan upaya khusus percepatan swasembada padi, jagung dan kedelai (Kemenkumham, 2015).

Provinsi Sumatera Barat salah satu provinsi yang terlibat dalam mengupayakan percepatan swasembada padi, jagung dan kedelai. Berdasarkan data yang diperoleh dari 
Badan Koordinasi Penyuluh Provinsi Sumatera Barat, dari 19 daerah kabupaten/kota ada 15 kabupaten/kota yang dilaksanakan program Upsus Pajale, hanya empat daerah yang tidak terlibat dalam program tersebut yaitu Kabupaten Kepulauan Mentawai, Kota Bukittinggi, Padang Panjang dan Solok. Artinya daerah kota yaitu Kota Padang, Payakumbuh, Padang Panjang, Bukittinggi, Pariaman, Solok dan Sawahlunto ikut dalam pelaksanaan program UPSUS PAJALE (upaya khusus percepatan swasembada padi, jagung dan kedelai).

Kota memang memiliki karakteristik yang berbeda dengan daerah kabupaten. Namun penduduk kota sama-sama membutuhkan pangan untuk melanjutkan keberlangsungan hidup mereka. Ketersediaan pangan di wilayah perkotaan sama pentingnya dengan ketersediaan pangan di daerah kabupaten. Karena jika dibandingkan kepadatan penduduk pada tahun 2015 dearah kota rata-rata sebanyak 1779,14 per $\mathrm{km}^{2}$, sedangkan untuk daerah kabupaten kepadatan penduduknya rata-rata hanya 123,9 per km² (BPS, 2016).

Berdasarkan data di atas bisa dikatakan bahwa kebutuhan pangan di daerah kota lebih besar dibandingkan daerah kabupaten. Oleh karena itu daerah kota yang struktur ekonominya didominasi oleh industri dan jasa dibutuhkan juga program upaya memenuhi kebutuhan pangan penduduknya. Meski kebutuhan pangan tersebut bisa diimpor dari daerah kabupaten tetapi banyak fenomena saat ini daerah kabupaten yang kekurangan ketersediaan pangan yang disebabkan karena banyak lahan di daerah yang dialihfungsikan untuk lahan tanaman perkebunan ataupun menjadi pemukiman.

Oleh karena itu penelitian ini bertujuan untuk: (1) mengidentifikasi komoditi pangan unggulan daerah kota di Provinsi Sumatera Barat. (2) menganalisis spesialisasi dan lokalisasi komoditi pangan unggulan daerah kota di Provinsi Sumatera Barat. (3) mengidentifikasi komoditi pangan prioritas yang bisa dikembangkan daerah kota di Provinsi Sumatera Barat.

\section{METODE}

\section{Lokasi dan Waktu Studi}

Penelitian ini dilakukan hanya di daerah kota yang ada di Provinsi Sumatera Barat yang berjumlah 7 Kota yaitu Kota Bukttinggi, Padang, Padangpanjang, Pariaman, Payakumbuh dan Sawahlunto. Data yang diamati terhadap 7 kota tersebut yaitu data tahun $2011-2015$.

\section{Jenis dan Pengumpulan Data}

Data yang digunakan dalam penelitian ini adalah data sekunder yang diperoleh melalui instansi atau lembaga-lembaga yang terkait dengan kegiatan penelitian ini, seperti: Badan Pusat Statistik (BPS) Provinsi Sumatera Barat, Badan Pembangunan Daerah (BAPPEDA) Sumatera Barat dan instansi lainnya yang berhubungan dengan penelitian ini. Data sekunder yang diperlukan dalam penelitian ini antara lain (1) Jumlah produksi komoditi pangan; (2) Harga masing-masing komoditi pangan; (3) Nilai produksi komoditi pangan, serta data lain yang berguna bagi penelitian ini. Data sekunder yang digunakan adalah data dari semua kota di Provinsi Sumatera Barat pada rentang waktu 2011 - 2015. Data yang digunakan adalah data time series (runut waktu).

\section{Teknik Analisis Data}

\section{Komoditi Unggulan Pangan Daerah Kota di Provinsi Sumatera Barat}

Alat analisis yang digunakan untuk mengidentifikasi komoditi basis yaitu Location Quotien (LQ). Alat analisis LQ merupakan suatu perbandingan tentang besarnya peranan suatu komoditas pertanian di suatu daerah terhadap besarnya peranan komoditas tersebut 
secara nasional (Tarigan, 2009). Tujuan analisis LQ yaitu untuk melihat suatu komoditi unggulan atau bukan unggulan. Perhitungan LQ dapat menggunakan rumus sebagai berikut:

$$
\mathrm{LQ}=\frac{\mathrm{pi} / \mathrm{pt}}{\mathrm{Pi} / \mathrm{Pt}}
$$

Secara lebih sederhana perhitungan LQ menurut Hendayana. R dalam (Hidayah, 2010) dapat diformulasikan sebagai berikut $p i$ adalah produksi komoditas 'i' pada tingkat kota, $p t$ adalah produksi total kelompok komoditas pada tingkat kota, $P i$ adalah produksi komoditas 'i' pada tingkat Provinsi, Pt adalah Produksi total kelompok komoditas pada tingkat Provinsi.

Di mana jika LQ $>1$ berarti sektor unggulan artinya komoditas i di suatu wilayah memiliki keunggulan komparatif, $\mathrm{LQ}=1$ berarti sektor non unggulan, artinya komoditas i di suatu wilayah tidak memiliki keunggulan, produksinya hanya cukup untuk memenuhi kebutuhan wilayah sendiri, dan LQ $<1$ berarti sektor non unggulan, artinya komoditas i di suatu wilayah tidak dapat memenuhi kebutuhan sendiri sehingga perlu pasokan dari luar. Di mana semakin tinggi nilai LQ sektor di suatu wilayah, semakin tinggi potensi keunggulan sektor tersebut.

\section{Spesialisasi dan Lokalisasi Komoditi Pangan Daerah Kota di Daerah Provinsi Sumatera Barat.}

Adanya spesialisasi dan lokalisasi dari komoditi pangan unggulan ditentukan dengan menggunakan metode gabungan LQ, Kuosien Spesialisasi (KS) dan Kuosien Lokalisasi (Lo) (Ropingi \& Sudartono, 2018).

\section{Kuosien Spesialisasi (KS)}

Penggunaan Kuosien Spesialisasi (KS) untuk mengetahui spesialisasi terhadap suatu kegiatan pertanian di suatu wilayah kota dan spesialisasi terhadap komoditi pangan tertentu di tingkat Provinsi Sumatera Barat. Nilai KS diperoleh dengan menggunakan rumus sebagai berikut:

$$
\mathrm{KS}=\left(\frac{\mathrm{w}_{\mathrm{i}}}{\mathrm{w}_{\mathrm{t}}}\right)-\left(\frac{\mathrm{w}_{\mathrm{i}}}{\mathrm{w}_{\mathrm{t}}}\right) \quad \mathrm{KS}=\sum_{\mathrm{p}=1}^{\mathrm{n}} \mathrm{KS}_{\mathrm{ip}}
$$

Di mana $K S$ adalah Kuosien spesialisasi terhadap komoditi i, wi adalah nilai produksi komoditi pangan i pada tingkat kota di Provinsi Sumatera Barat, wt adalah nilai produksi total komoditi pangan-pada tingkat kota di Provinsi Sumatera Barat, $W i$ adalah nilai produksi komoditi pangan i pada wilayah Provinsi Sumatera Barat, Wt adalah nilai produksi total komoditi pangan pada wilayah Provinsi Sumatera Barat, $K S$ adalah kousien spesialisasi dan KSip adalah KSi positif. Jika nilai KS kota mendekati satu atau KS $\geq 1$ maka di tingkat kota terdapat spesialisasi terhadap kegiatan komoditi pangan. Dan jika KS mendekati nol atau KS $=0$ maka di tingkat kota tidak terdapat spesialisasi terhadap kegiatan komoditi pangan.

\section{Kuosien Lokalisasi (Lo)}

Penggunaan Kuosien Lokalisasi (Lo) untuk mengetahui tingkat penyebaran kegiatan pertanian di suatu wilayah kota dan tingkat penyebaran komoditi pangan tertentu di Provinsi Sumatera Barat. Untuk menghitung nilai Lo digunakan rumus sebagai berikut:

$$
\mathrm{Lo}_{\mathrm{i}}=\left(\frac{\mathrm{w}_{\mathrm{i}}}{\mathrm{w}_{\mathrm{i}}}\right)-\left(\frac{\mathrm{w}_{\mathrm{t}}}{\mathrm{w}_{\mathrm{t}}}\right) \quad \mathrm{Lo}=\sum_{\mathrm{p}=1}^{\mathrm{n}} \mathrm{Lo}_{\mathrm{ip}}
$$

Di mana Loi adalah kuosien lokalisasi terhadap komoditi i, wi adalah nilai produksi komoditi pangan i pada tingkat kota di Provinsi Sumatera Barat, wt adalah nilai produksi total komoditi pangan pada tingkat kota di Provinsi Sumatera Barat, Wi adalah nilai produksi komoditi pangan i pada wilayah Provinsi Sumatera Barat, $W t$ adalah nilai produksi total komoditi pangan-pada wilayah Provinsi Sumatera Barat, Lo adalah kousien spesialisasi dan Loip adalah KSi positif. Jika nilai Lo kota mendekati satu atau Lo $\geq 1$ maka di tingkat kota 
terjadi pemusatan terhadap kegiatan komoditi pangan. Dan jika Lo mendekati nol atau KS = 0 maka di tingkat kota tidak terjadi pemusatan terhadap kegiatan komoditi pangan.

\section{Komoditi Prioritas Pangan Daerah Kota di Provinsi Sumatera Barat.}

Untuk menentukan komoditi pangan yang menjadi prioritas untuk dikembangkan yaitu berdasarkan analisis gabungan dengan melihat nilai LQ terbesar dan KS paling tinggi dari komoditi pangan di tiap kota. Semakin besar nilai LQ suatu komoditi maka semakin besar pula potensi keunggulan komoditi tersebut. Dan begitu juga jika nilai kuosien spesialisasinya paling tinggi dari berbagai komoditi yang ada berarti komoditi tersebut mempunyai keunggulan komparatif untuk diproduksi di kota tersebut. Komoditi pangan yang memiliki LQ terbesar dan KS tertinggi yang dapat diprioritaskan untuk dikembangkan lebih baik lagi di suatu daerah.

\section{HASIL DAN PEMBAHASAN}

\section{Komoditi Unggulan Pangan Daerah Kota di Provinsi Sumatera Barat}

Komoditi unggulan pangan daerah kota di Provinsi Sumatera Barat diketahui berdasarkan nilai LQ yang dihitung berdasarkan nilai produksi komoditi pangan pada tahun 2011 - 2015. Berdasarkan hasil analisis LQ yang telah dilakukan menunjukkan bahwa komoditi unggulan pajale di daerah didominasi oleh komoditi padi (lihat Tabel 1). Seluruh daerah kota di Provinsi Sumatera Barat memiliki komoditi unggulan padi karena memiliki nilai LQ $>1$. Hal ini menunjukkan bahwa komoditi padi memiliki nilai produksi lebih besar dibandingkan komoditi pangan lainnya. Dan komoditi jagung tidak menjadi komoditi unggulan di semua daerah kota di Provinsi Sumatera Barat karena memiliki nilai LQ $<1$. Sedangkan untuk komoditi kedelai hanya di Kota Sawahlunto yang menjadi komoditi unggulan karena memiliki nilai LQ-nya sebesar 1,52.

Tabel 1. Nilai LQ Komoditi Pajale Daerah Kota Provinsi Sumatera Barat Tahun 2011 - 2015

\begin{tabular}{clccc}
\hline No & \multicolumn{1}{c}{ Kota } & Padi & Nagung & Kedelai \\
\hline 1 & Padang & 1,18 & 0,00 & 0,04 \\
2 & Solok & 1,13 & 0,19 & 0,00 \\
3 & Sawahlunto & 1,12 & 0,02 & 1,52 \\
4 & Padang Panjang & 1,15 & 0,03 & 0,00 \\
5 & Bukit Tinggi & 1,02 & 0,07 & 0,00 \\
6 & Payakumbuh & 1,07 & 0,23 & 0,00 \\
7 & Pariaman & 1,18 & 0,05 & 0,45 \\
\hline
\end{tabular}

Sumber: Hasil Analisis

Komoditi jagung tidak menjadi komoditi unggulan di semua daerah kota karena jika dibandingkan dengan komoditi lain memang nilai produksinya relatif rendah dibandingkan dengan yang lain. Dan nilai produksinya juga relatif rendah dibandingkan nilai produksi jagung dari daerah kabupaten/kota lainnya yang ada di Provinsi Sumatera Barat. Dan Kota Sawahlunto menjadi satu-satunya daerah kota yang memiliki komoditi unggulan kedelai. Karena jika dibandingkan nilai produksinya relatif lebih besar dibandingkan dengan nilai produksi komoditi pangan dan daerah kota yang lain. 


\section{Spesialisasi dan Lokalisasi Komoditi Pangan Daerah Kota di Daerah Provinsi Sumatera Barat.}

Nilai KS menunjukkan spesialisasi terhadap suatu kegiatan pertanian di suatu wilayah kota dan spesialisasi terhadap komoditi pangan tertentu di tingkat Provinsi Sumatera Barat. Dimana jika nilai KS kota mendekati satu atau KS $\geq 1$ maka di tingkat kota terdapat spesialisasi terhadap kegiatan komoditi pangan. Dan jika KS mendekati nol atau KS = 0 maka di tingkat kota tidak terdapat spesialisasi terhadap kegiatan komoditi pangan.

Berdasarkan hasil analisis menunjukkan bahwa tidak ada satu pun komoditi pajale yang memiliki nilai KS $\geq 1$ (lihat Tabel 2). Artinya daerah kota di Provinsi Sumatera Barat tidak terdapat spesialisasi terhadap kegiatan komoditi pajale. Meskipun semua kota memiliki nilai LQ $>1$ bukan berarti daerah tersebut terspesialisasi terhadap komoditi tersebut.

Tabel 2. Nilai KS Komoditi Pajale Daerah Kota di Provinsi Sumatera Barat Tahun 2011 - 2015

\begin{tabular}{clccc}
\hline \multicolumn{1}{c}{ Kota } & \multicolumn{2}{c}{ Nilai KS } \\
\cline { 3 - 5 } & & Padi & Jagung & Kedelai \\
\hline 1 & Padang & 0,150 & 0,120 & 0,001 \\
2 & Solok & 0,108 & 0,097 & 0,001 \\
3 & Sawahlunto & 0,100 & 0,117 & 0,000 \\
4 & Padang Panjang & 0,127 & 0,116 & 0,001 \\
5 & Bukittinggi & 0,015 & 0,111 & 0,001 \\
6 & Payakumbuh & 0,056 & 0,093 & 0,000 \\
7 & Pariaman & 0,144 & 0,114 & \\
\hline
\end{tabular}

Sumber: Hasil Analisis

Berdasarkan hasil analisis Lo pada Tabel 3. yang menunjukkan bagaimana tingkat penyebaran kegiatan pertanian. Di mana Jika nilai Lo kota mendekati satu atau Lo $\geq 1$ maka di tingkat kota terjadi pemusatan terhadap kegiatan komoditi pangan. Dan jika Lo mendekati nol atau KS = 0 maka di tingkat kota tidak terjadi pemusatan terhadap kegiatan komoditi pangan. Dan berdasarkan Tabel 3 menunjukkan bahwa di seluruh daerah kota tidak menunjukkan terjadinya pemusatan terhadap kegiatan pertanian pajale. Karena nilai Lo $\leq 1$ artinya kegiatan pertanian pajale menyebar di daerah kecamatan-kecamatan yang ada di kota tersebut.

Tabel 3. Nilai Lo Daerah Kota di Provinsi Sumatera Barat Tahun 2011 - 2015

\begin{tabular}{clccc}
\hline \multirow{2}{*}{ No Kota } & \multicolumn{3}{c}{ Nilai Lo } \\
\cline { 3 - 5 } & & Padi & Jagung & Kedelai \\
\hline 1 & Padang & 0,005 & $-0,029$ & $-0,028$ \\
2 & Solok & 0,001 & $-0,004$ & $-0,005$ \\
3 & Sawahlunto & 0,001 & $-0,006$ & 0,003 \\
4 & Padang Panjang & 0,000 & $-0,003$ & $-0,003$ \\
5 & Bukittinggi & 0,000 & $-0,002$ & $-0,002$ \\
6 & Payakumbuh & 0,001 & $-0,011$ & $-0,014$ \\
7 & Pariaman & 0,002 & $-0,009$ & $-0,006$ \\
\hline
\end{tabular}

Sumber: Hasil Analisis

\section{Komoditi Prioritas Pangan Daerah Kota di Provinsi Sumatera Barat.}

Komoditi prioritas ditentukan berdasarkan nilai LQ dan KS dimana jika nilai LQ > 1 dan nilai KS $\geq 1$ atau mendekati 1 berarti komoditi tersebut bisa dijadikan komoditi prioritas untuk dikembangkan di daerah kota yang ada di Provinsi Sumatera Barat. Berdasarkan pertimbangan tersebut maka komoditi padi menjadi komoditi prioritas di beberapa kota yaitu Kota Padang, Solok, Sawahlunto, Padang Panjang dan Pariaman. Dan komoditi jagung 
tidak bisa menjadi prioritas di semua kota karena nilai $\mathrm{LQ}<1$ dan nilai $\mathrm{KS}$ tidak ada yang $\geq$ 1 atau mendekati 1 . Sama halnya dengan komoditi kedelai tidak menjadi komoditi prioritas di kota manapun. Meskipun nilai LQ kedelai di Kota Sawahlunto lebih besar dari 1 namun nilai KS-nya hanya 0 sehingga komoditi tersebut tidak bisa menjadi komoditi prioritas di Kota Sawahlunto.

Tabel 4. Komoditi Prioritas Daerah Kota di Provinsi Sumatera Barat

\begin{tabular}{llllllll}
\hline \multirow{2}{*}{ No } & \multirow{2}{*}{ Kota } & \multicolumn{2}{c}{ Padi } & \multicolumn{2}{c}{ Jagung } & \multicolumn{2}{c}{ Kedelai } \\
\cline { 3 - 7 } & LQ & KS & LQ & KS & LQ & KS \\
\hline 1 & Padang & 1,18 & 0,150 & 0,00 & 0,120 & 0,04 & 0,001 \\
2 & Solok & 1,13 & 0,108 & 0,19 & 0,097 & 0,00 & 0,001 \\
3 & Sawahlunto & 1,12 & 0,100 & 0,02 & 0,117 & 1,52 & 0,000 \\
4 & Padang Panjang & 1,15 & 0,127 & 0,03 & 0,116 & 0,00 & 0,001 \\
5 & Bukittinggi & 1,02 & 0,015 & 0,07 & 0,111 & 0,00 & 0,001 \\
6 & Payakumbuh & 1,07 & 0,056 & 0,23 & 0,093 & 0,00 & 0,001 \\
7 & Pariaman & 1,18 & 0,144 & 0,05 & 0,114 & 0,45 & 0,000 \\
\hline
\end{tabular}

Sumber: Hasil Analisis

\section{KESIMPULAN}

Komoditi pangan unggulan di daerah kota Provinsi Sumatera Barat yaitu Padi dan Kedelai khusus untuk Kota Sawahlunto. Semua komoditi pangan unggulan (pajale) daerah kota di Provinsi Sumatera Barat tidak terspesialisasi dan juga tidak terjadi pemusatan (lokalisasi). Sedangkan untuk komoditi prioritas yang perlu dikembangkan di daerah kota Provinsi Sumatera Barat adalah komoditi Padi yang bisa dikembangkan di Kota Padang, Solok, Sawahlunto, Padang Panjang dan Pariaman.

\section{DAFTAR PUSTAKA}

BPS. (2016). Produksi Tanaman Pangan: Angka Tetap Tahun 2015. Jakarta: Badan Pusat Statistik.

Hidayah, I. (2010). Analisis Prioritas Komoditas Unggulan Perkebunan Daerah Kabupaten Buru. Maluku: AGRIKA.

Horridge, M., Wittwer, G., \& Wibowo, K. (2006). Dampak Dari Kebijakan Impor Beras Nasional Terhadap Perekonomian Jawa Barat: Simulasi Menggunakan Model CGE Indoterm. Sosiohumaniora, 224-239.

Kemenkumham. (2015). permen. Diambil kembali dari peraturan.go.id: http://peraturan.go.id/permen/kementan-nomor-14-permentan-ot.140-3-2015-tahun-2015.html

Lassa, J. (2005). Politik Ketahanan Pangan Indonesia 1950 - 2005. Diambil kembali dari www.zef.de: https://www.zef.de/uploads/tx_zefportal/Publications/3ddf_Politik\%20Ketahanan\%20Pangan\%20I ndonesia\%201950-2005.pdf

Pertanian, K. (2015). Outlook Komoditi Pertanian Subsektor Tanaman Pangan:Jagung. Jakarta: Kementerian Pertanian.

Pertanian, K. (2015). Outlook Komoditi Pertanian Subsektor Tanaman Pangan:kedelai. Jakarta: Kementerian Pertanian.

Pertanian, K. (2015). Outlook Komoditi Pertanian Subsektor Tanaman Pangan:padi. Jakarta: Kementerian Pertanian.

Prabowo, R. (2010). Kebijakan Pemerintah dalam Mewujudkan Ketahanan Pangan di Indonesia. Jurnal Mediagro, 62-73.

Rachmat, M. (2015). Tantangan dan Strategi Percepatan Pencapaian Ketahanan Pangan yang Mandiri dan Berdaulat. IAARD Press, 313.

Ropingi, \& Sudartono, Y. (2018). Pembangunan Wilayah Kecamatan Berbasis Komoditas Pertanian di Kabupaten Gunungkidul Provinsi Daerah Istimewa Yogyakarta. Jurnal Ilmu-Ilmu Pertanian, Vol.4.

Sumarno. (2015). Kemandirian Pangan Nasional Mengapa Sulit Dicapai dan Apa yang Harus Dilakukan . IAARD PRESS, 283.

Tarigan, R. (2009). Ekonomi Regional: Teori dan Aplikasi. Jakarta: Bumi Aksara. 